\title{
Examples of lake disappearance as an effect of reclamation works in Poland
}

\author{
Adam Choiński ${ }^{1}$, Mariusz Ptak ${ }^{1}$, Agnieszka Strzelczak ${ }^{2}$ \\ ${ }^{1}$ Institute of Physical Geography and Environmental Planning, Adam Mickiewicz University, Dzięgielowa 27, 61-680 Poznań, Poland, \\ e-mail: choinski@amu.edu.pl,marp114@wp.pl \\ ${ }^{2}$ Faculty of Food Sciences and Fisheries, West Pomeranian University of Technology in Szczecin, Pawła VI 3, 71-459 Szczecin, Poland, \\ e-mail: Agnieszka-Strzelczak@zut.edu.pl
}

\begin{abstract}
Glacial lakes undergo evolution with their disappearance as the last stage of it. Natural processes which determine the rate of lake shrinking occur rather slowly but they have been increasing their speed with the stronger human interference in the environment. The most drastic effect of anthropogenic pressure exerted on lake ecosystems is their complete disappearance caused by reclamation works. One can state that this process is a change of rapid character (a lake can disappear within a few years or several decades, in extreme cases even within one year). Drainage works are particularly unfavourable in areas with a shortage of water supplies, where rapid lake shallowing reduces water retention even more. A considerable part of Poland suffers from water supply deficiency. Therefore, draining of lakes should be considered as an adverse operation. This study discusses the examples of eleven lakes located in Poland and subjected to reclamation works. Analyses of those cases lead us to the conclusion that drainage aiming to broaden agricultural areas has not always been proper.
\end{abstract}

Key words: reclamation, lake, environmental transformation, anthropopressure

\section{Introduction}

Humanity, by adapting the natural environment to its increasing needs, has been distinctly changing its features. Civilization development was particularly intensive in the $18^{\text {th }}$ and $19^{\text {th }}$ centuries and resulted in the adaptation of larger areas, unavailable until then. Those actions mainly focused on deforestation and drainage of wetlands. The $20^{\text {th }}$ century brought even deeper interference in the environment, which particularly affected hydrological conditions. Water was one of the determinants of dynamic development, crucial for industry, agriculture, settlement, etc. All those factors contributed to the substantial deterioration of water quality and water supply depletion. Lakes play a very important role in water management since they, as opposed to rivers, provide stability in water supplies. However, their role in the environment was underestimated, which generated actions leading to their removal from the landscape. Lakes connected with the latest glaciation undergo evolution with their dis- appearance as the last stage. Natural processes which trigger the shrinkage of lake area (due to oscillations in water level and succession) as well as the increase in bottom sediment thickness are rather slow. Stronger anthropopression has considerably increased the rate of changes. Regarding lake ecosystems, reclamation works aiming to drain those water bodies are the most extreme example of human impact on the environment. They lead to a quick disappearance of a lake depending on its area even within a few years. In the young glacial zone it was large-area drainage of river valleys as well as precise drainage of lakes that prevailed among reclamation works. The conditions for such actions were various but most often the aim was to broaden agricultural areas.

Changes in the areas of lakes in Poland are well documented (Churski 1983; Choiński 2001; Kowalewski et. al. 2001; Bartczak 2003; Kowalewski 2003; Choiński and Ptak 2008; Kunz et. al 2010; Choiński et.al. 2011; Marszelewski et. al. 2011; Nowak et. al. 2011; Kowalewski 2011; Ptak and Ławniczak 2011). 
Melioration works which aim to drain a given water body belong to human activities which have an extreme influence on the functioning of lake ecosystems. Such treatments, through the outflow of water, lead to a quick shrinkage of lake area or even its complete disappearance (Babiński 1988; Glazik 1988; Kaniecki 1997a; Superson and Szwajgier 2003; Ptak et. al. 2013) - depending on the size of a lake it can even take only a few years.

This study presents examples of lakes which have been completely drained.

\section{Study area and methods}

The selection of lakes analysed in this study was random in order to show that the phenomenon of drainage of natural water bodies occurred in the area of all three lake districts in Poland (i.e. Pomeranian, Masurian and Greater Poland-Kuyavian, Fig. 1). The investigation covered lakes with various surface areas.

This study is based on cartographic documents from the $19^{\text {th }}$ century and the beginning of the $20^{\text {th }}$ century - Prussian maps Messtischblatter (1:25000) as well as thematic maps based on them: geological Geologische Karte von Preussen und benachbarten Bundesstaaten (1:25000) and the map of the soil Geog-

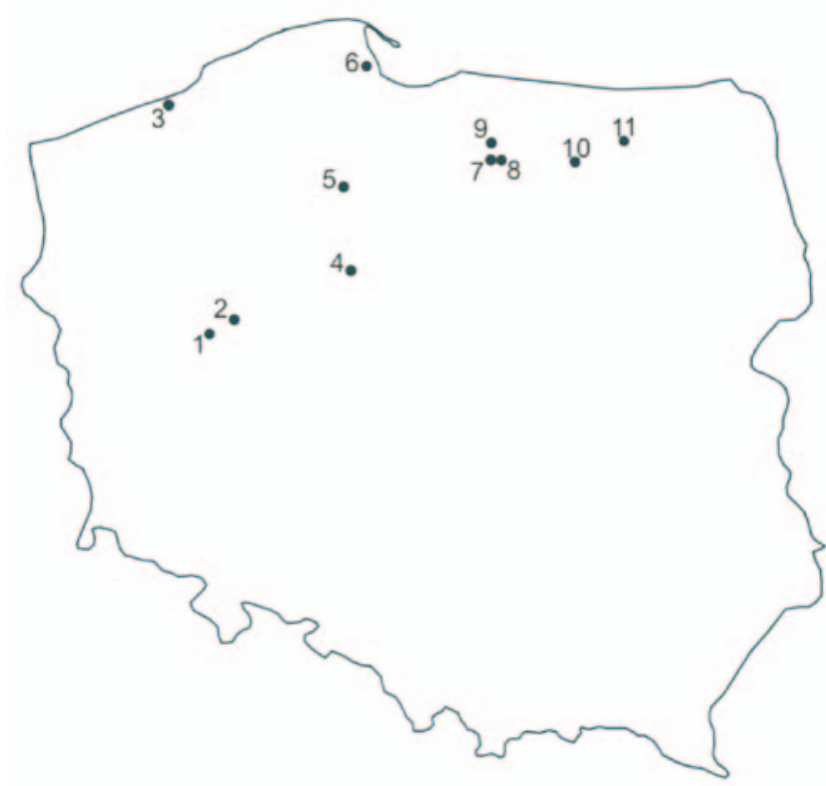

Fig. 1. Location of lakes that underwent drainage works: 1 - Zgierzynieckie, 2 - Objezierze, 3 - Kazimierskie, 4 - Studziennicze, 5 - Gacno, 6 - Wielki Kack, 7 - Garzen 1, 8 - Garzen 2, 9 - Morąg, 10 - Dymer, 11 - Wąż.
nostisch-Agronomisch (1:25000). These maps are fully cartometric and, therefore, allowed the surface areas of non-existent lakes to be established. Their shorelines were determined based on organic deposits, marked on the maps as peats. The orthophotomap and photographs taken in field surveys allowed the current state of the drained lakes to be presented. There are altogether eleven water bodies discussed in this paper. Their areas were calculated in MapInfo software.

\section{Results}

The areas covered by the non-existent lakes are presented in Figure 2. It shows the lakes before reclamation works, at the beginning of the $20^{\text {th }}$ century and the current state.

The presence of a currently functioning network of melioration ditches is a characteristic feature of the areas formed after reclamation works. Hydrotechnical treatments, depending on lake size and depth, brought the formation of networks of various density. Areas of lakes which underwent drainage are given in Table 1.

The total area of lakes that disappeared as a result of reclamation works amounted to 1842.9 ha and, for example, it is comparable to the area of Lake Roś

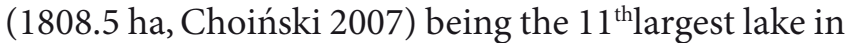
Poland. Lake Wąż was the largest of the drained lakes and its area before drainage reached almost 450 ha.

The current state of the lands which used to be lake basins shows that not in all cases was the goal of reclamation works rational. It is particularly clear for Lake Objezierze - after drainage the former lake area

Table 1. Surface areas (in hectares) of lakes which underwent drainage works

\begin{tabular}{clc}
\hline No. & Lake name & Surface area before drainage \\
\hline 1 & Zgierzynieckie & 66.0 \\
2 & Objezierze & 110.0 \\
3 & Kazimierskie & 383.0 \\
4 & Studziennicze & 102.0 \\
5 & Gacno & 121.0 \\
6 & Wielki Kack & 21.9 \\
7 & Garzen 1 & 35.3 \\
8 & Garzen 2 & 27.0 \\
9 & Morąg & 146.7 \\
10 & Dymer & 381.0 \\
11 & Wąż & 449.0 \\
\hline
\end{tabular}


before reclamation

1891

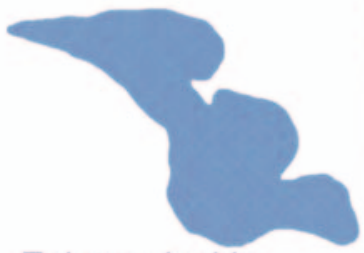

Zgierzynieckie Lake
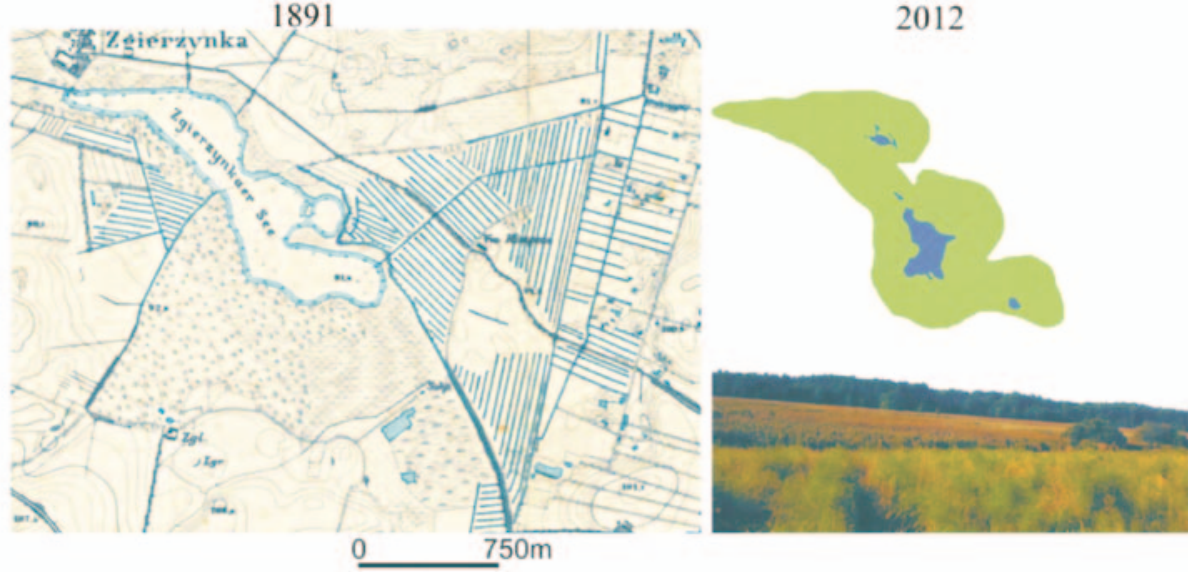

before reclamation

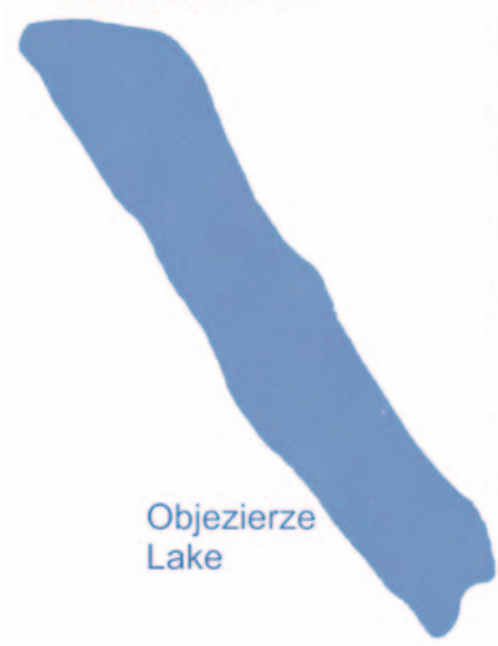

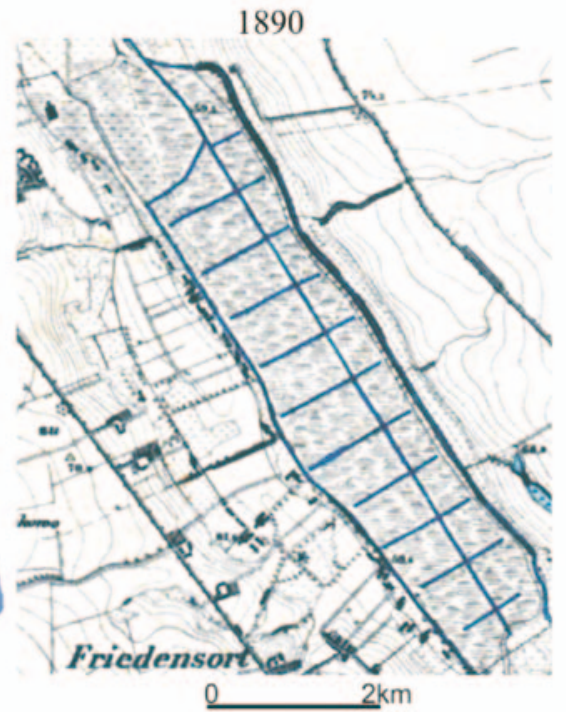

2012
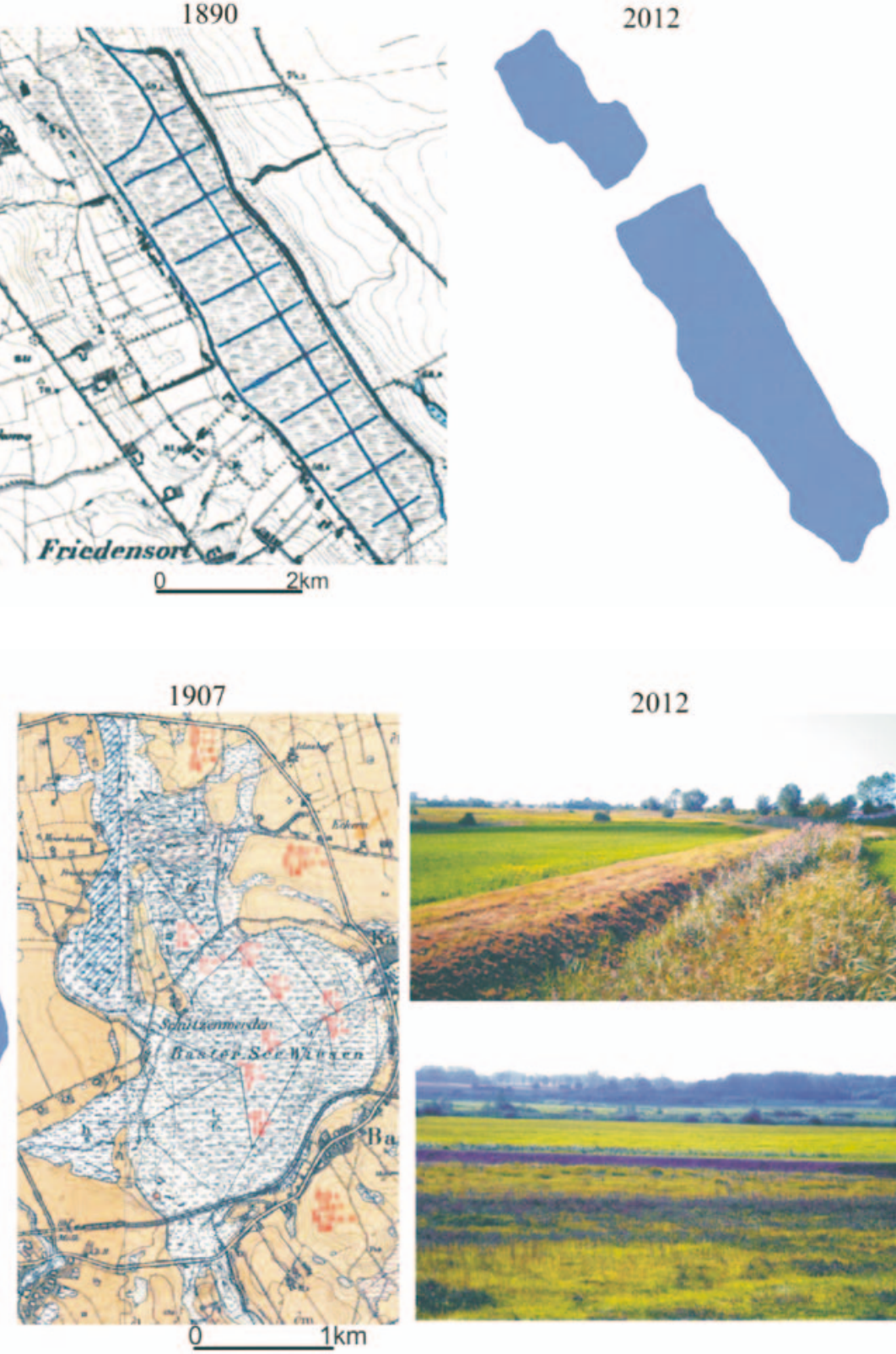

2012

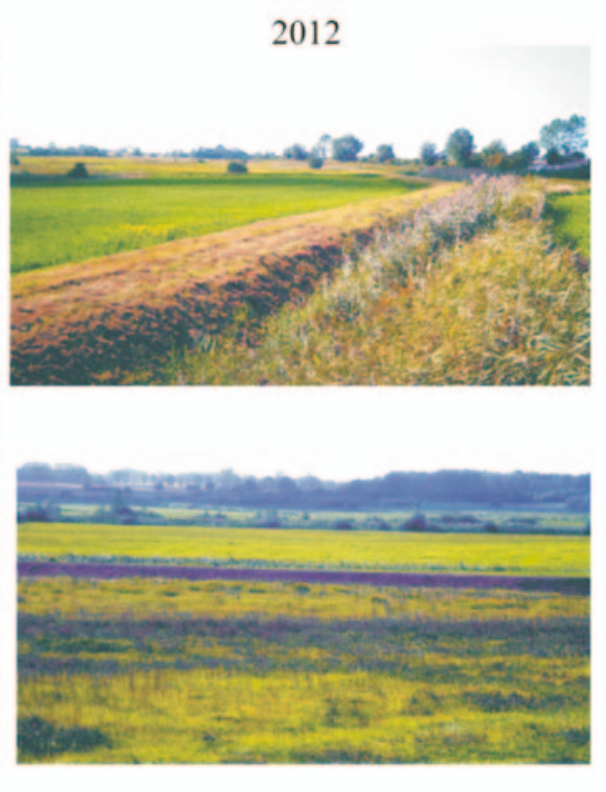



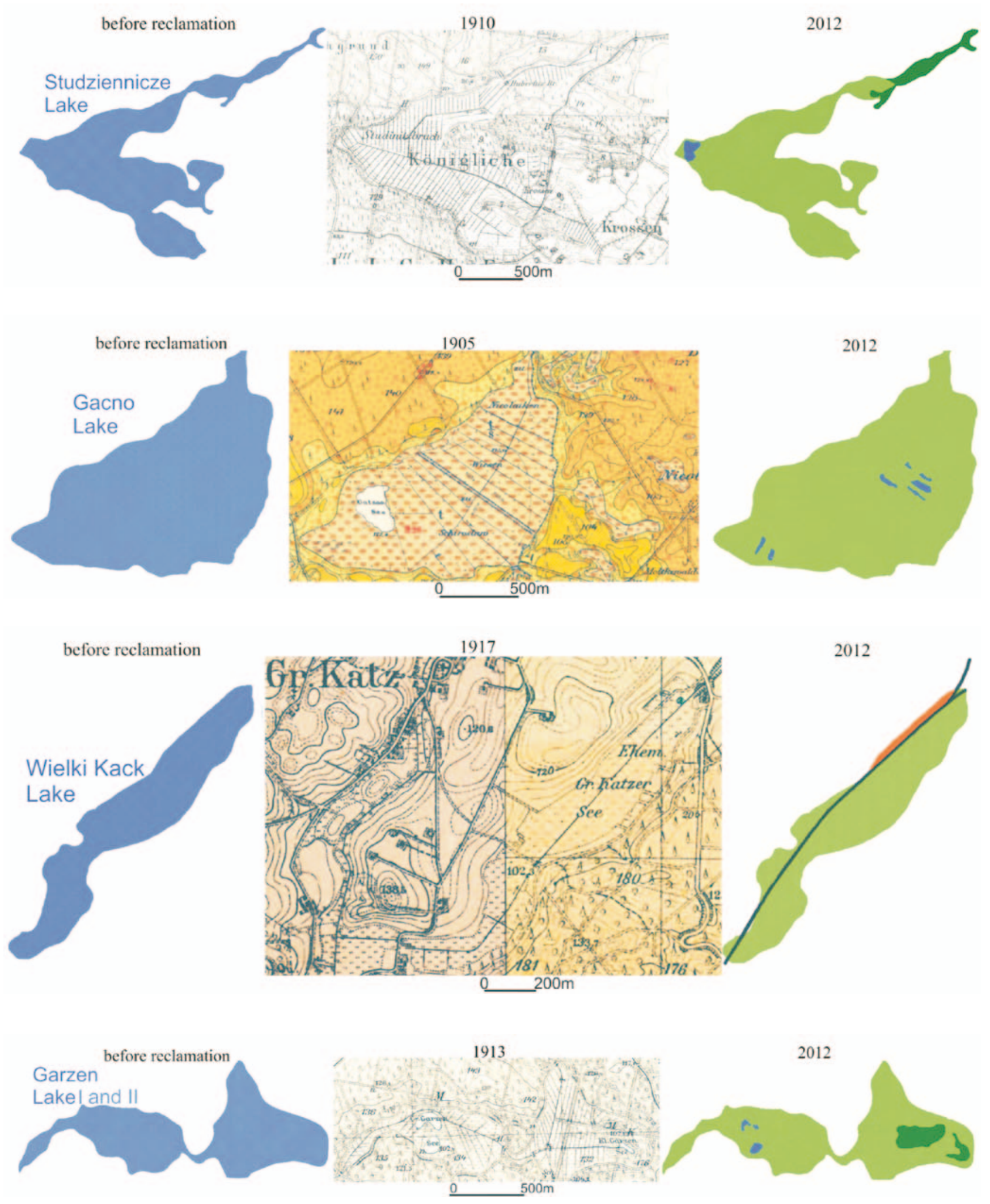

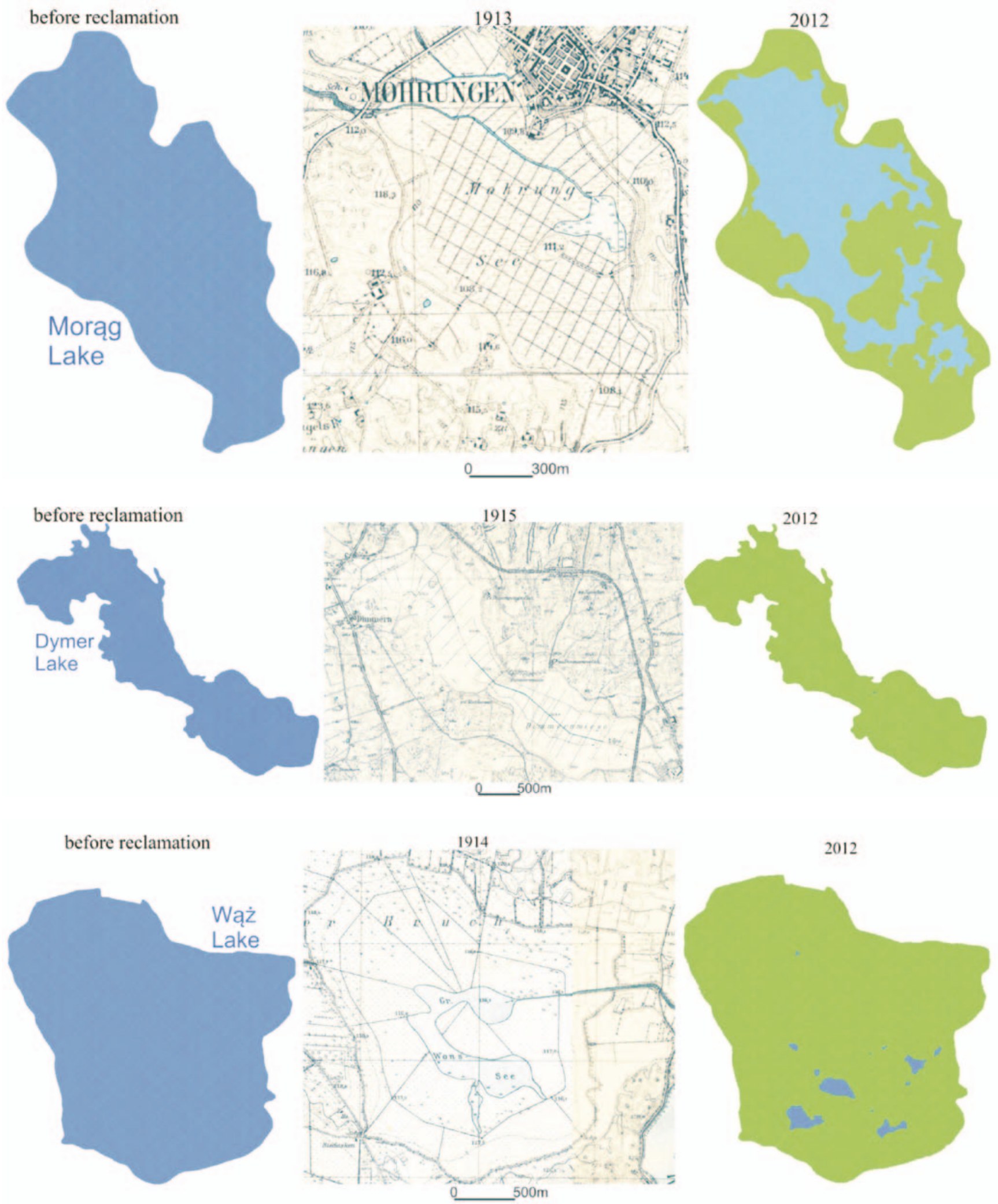

\section{Legend}

$\square$ water $\square$ grasslands ; aquatic and rush vegetation $\square$ forest $\square$ buildings $\boxminus$ railway

Fig. 2. Examples of drainage of lakes (their location is presented in Fig. 1) 
was covered by meadows but now ponds constitute a considerable part of it. Therefore, one can conclude that the presence of water there was more justified than the transformation into agricultural land. Taking into consideration the present situation, it seems that the decision about drainage was incorrect. Highly efficient melioration systems are indispensable to ensure hydrographic conditions sufficient for the good functioning of the transformed lands. That involves systematic scything of melioration ditches, clearing of their bottom, etc. These treatments need additional expenditures while their renunciation causes "the return of water" and the transition of a former lake area into a floodplain (e.g. Morąskie flood plain - former Lake Morag). Consequently, the drained area becomes a waste land and no measurable profits can be gained from it - neither from agriculture nor from a lake (tourism, fishery, production of energy, etc.). On the other hand, the diversity of plant and animal species typical of wetlands is a virtue of such lands. Some of those species are very valuable and protection zones have been created in the areas of their occurrence (e.g. the reserve "Rezerwat na Jeziorze Zgierzynieckim").

As was mentioned in the Introduction section, the lakes were drained mainly in order to gain new arable lands. That finds confirmation in the case of the lakes discussed in this paper - among eleven water bodies there are as many as seven lakes which are currently used this way. However, not always was the agricultural purpose the key factor - the present grasslands are a consequence of other objectives. Such a situation concerned, for instance, the lakes of Kack Wielki and Morag. In the first case, a railway (coal thoroughfare) runs through the area of the former lake. It was built at the beginning of the 1920s while the lake was drained earlier (the first decade of the $20^{\text {th }}$ century). However, those facts should be considered as connected with each other because the land preparation for the sake of the railway (heavy earth moving equipment, prevention of ground settling, etc.) must have been performed early enough. In turn, Lake Morag underwent severe eutrophication as a result of piping the sewage from the town. It was assessed that in its trophic state the lake posed a threat to people and with the acceptance of the authorities of Morag it was decided to start reclamation works in 1867.

\section{Conclusions}

Reclamation works conducted in large areas since the $18^{\text {th }}$ century exerted an impact on all the components of the hydrosphere. The assumptions of those treatments were often incorrect. Drainage focused on river valleys and in the case of lakes it caused a significantly greater decrease in water level compared to the original goals. Kaniecki (1997b) reported that the level of water in Lake Mielno dropped by $116 \mathrm{~cm}$ (planned $-114 \mathrm{~cm}$ ), for Lake Sadłodzińskie it was $130 \mathrm{~cm}$ (planned $-114 \mathrm{~cm}$ ) and in the case of Łudzisko it decreased by $61 \mathrm{~cm}$ (planned $-46 \mathrm{~cm}$ ).

Expansionist human operations considerably influence hydrographic conditions, which is perfectly visible in the example of lakes that disappeared as a result of drainage works. The evolution of glacial lakes is gradual - they go through consecutive stages of their development and that process, depending on the size of a water body, may last even a few thousand years (Choiński 2007). This study presents the cases of lakes subjected to anthropopression which completely disappeared within a few years or several decades. It should be underlined that such actions are an extremely negative example of human impact on lake ecosystems. They considerably accelerate natural processes connected with lake shallowing (in general rather slow) as well as those being the result of anthropopressure (e.g. increased rate of eutrophication triggered by the supplies of nutrients from arable lands). The problem of lake drainage is important not only in Poland (Gryaznova 1992; Soto et al. 2011; Du et al. 2011) and the objectives as well as the effects of such treatments are diverse. Reclamation works, besides rapid transformations of the natural environment, also brought changes in human life. It was stated, among others, by Ptak et al. (2013), who underlined that the drainage of Lake Jelenino caused the inhabitants of Jelenino village to lose their jobs. They used to live by fishery and in a short period of time they had to face a rapid social and economic transformation (retrained for agriculture and breeding).

Rapid operations such as complete drainage of lakes are still an issue insufficiently emphasized while the consequences of those treatments are severely unfavourable also in terms of water balance. The disappearance of lakes located in lands afflicted by a shortage of water supplies (like a considerable part of Poland) deepens even further the water supply depletion by a decreased retention in a given area. 


\section{References}

Babiński Z., 1988, Wpływ melioracji na zmiany zwierciadła i powierzchni wody jeziora Pniewite (Influence of land reclamation on changes in water level and water area of Lake Pniewite), [in:] Churski Z. (ed.), Naturalne i antropogeniczne przemiany jezior i mokradeł w Polsce (Natural and anthropogenic transformations of lakes and wetlands in Poland), Wyd. UMK, Toruń: 101-104 (in Polish).

Bartczak A., 2003, Natural and anthropogenic changes of the lake areas within the region of Eastern Kujawy in the Zgłowiączka River basin, Limnol. Rev. 3: 9-16.

Choiński A., 2001, Analysis of changes in the area and volume of Lake Jamno, Limnol. Rev. 1: 41-45.

Choiński A., 2007, Limnologia fizyczna Polski (Physical limnology of Poland), Wyd. Nauk. UAM, Poznań, p. 547 (in Polish).

Choiński A., Ławniczak A.E., Ptak M., Sobkowiak L., 2011, Causes of lake area changes in Poland, J. Resour. Ecol. 2(2): 175-180.

Choiński A., Ptak M., 2008,_Zanikanie jezior w Wielkopolsce na tle Polski (The Wielkopolska lakes shrinkage against the background of Poland), Rocz. Glebozn. 59(2): 25-31 (in Polish, English summary).

Churski Z., 1983, Eutrophication and the disappearance of lakes in the Brodnica Lake District, Northen Poland as a result of human interference, Hydrobiologia 103(1): 165-168.

Du Y., Xue H.-P., Wu S.-J., Ling F., Xiao F., Wei X.-H., 2011, Lake area changes in the middle Yangtze region of China over the 20th century, J. Environ. Manage. 92(4), 1248-1255.

Gryaznova T.P., 1992, Human impacts in the Aral Basin as depicted on space imagery, Mapp. Sci. Rem. Sens. 29(1): 78-83.

Glazik R., 1988, Naturalne i antropogeniczne zmiany powierzchni jezior i mokradeł w zachodniej części Kotliny Płockiej (Natural and anthropogenic changes in lake and wetland areas of the western part of the Płock Basin), [in:] Churski Z. (ed.), Naturalne i antropogeniczne przemiany jezior i mokradeł w Polsce (Natural and anthropogenic transformations of lakes and wetlands in Poland), UMK, Toruń: 105-107 (in Polish).

Kaniecki A., 1997a, The influence of anthropopressure on water relations in the Wielkopolska Lowland, Geogr. Pol. 68: 78-80.
Kaniecki A., 1997b, Wpływ XIX-wiecznych melioracji na poziom wód (Influence of reclamation in the $19^{\text {th }}$ century on changes in water level), [in:] Choiński A. (ed.), Wpływ antropopresji na jeziora (Influence of anthropopression on lakes), Wyd. Homini, Poznań-Bydgoszcz: 67-72 (in Polish).

Kowalewski G., 2003, Shoreline changes of basins in the mire - lake reserves in S Tuchola pinewoods, Limnol. Rev. 3: 119-127.

Kowalewski G., 2011, Shoreline and surface area changes induced by floating islands in peatland lakes (Tuchola Pinewood Forest, Poland), Limnol. Rev. 4: 135-169.

Kowalewski G., Lamentowicz, Pająkowski J., 2001, Lake Miedzino shoreline changes and Lake Piaseczno sediments in Wdecki Landscape Park area, Limnol. Rev. 1: 173-181.

Kunz M., Skowron R., Skowroński S., 2010, Morphometry changes of Lake Ostrowskie (the Gniezno Lakeland) on the basis of cartographic, remote sensing and geodetic surveying, Limnol. Rev. 10(2): 77-87.

Marszelewski W., Ptak M., Skowron R., 2011, Antropogeniczne i naturalne uwarunkowania zaniku jezior na Pojezierzu Wielkopolsko-Kujawskim (Anthropogenic and natural conditionings of lakes disappearing in the Wielkopolska-Kujawy Lake District), Rocz. Glebozn. 62(2): 283-294 (in Polish, English summary).

Nowak B., Brodzińska B., Gezella-Nowak I., 2011, Natural and economic factors of shrinkage of lakes of the Wielkopolska Lakeland, Limnol. Rev. 11(3): 97-132.

Ptak M., Choiński A., Strzelczak A., Targosz A., 2013, Disappearance of lake Jelenino since the end of XVIII century as an effect of anthropogenic transformations of the natural environment, Pol. J. Environ. Stud. (in press).

Ptak M., Ławniczak E.A., 2011, Changes in water resources in selected lakes in middle and lower catchment of River Warta, Limnol. Rev. 11(1): 25-33.

Soto M.F., García A.F., Cuesta G.F., Prieto J.R.F., 2011, La desecación de la laguna de Antela (The drying of Antela lake), B. Asoc. Geogr. Esp. 57: 295-312 (in Spanish, English summary).

Superson J., Szwajgier W., 2003, Natural and anthropogenic conditioning of the changes of the shoreline of Brudno, Brudziec and Płotycze lakes (the Łęczna - Włodawa Lake District), Limnol, Rev. 3: 223-229. 